\title{
The Native and his Industries in Northern Rhodesia*
}

\author{
By Prof. Alan G. Ogilvie, o.B.e.
}

$\mathrm{E}^{\mathrm{v}}$ VER since geography was re-established as an organised discipline, the essence of which is the study of terrestrial distributions and their inter-relations, geographers have been sifting and collating data of extremely varied character. The facts which have thus been incorporated in the body of geographical literature have themselves usually been established by workers in other fields, while geographers have drawn deductions from them, in many cases without having the opportunity to test their validity on the ground. As a result, generalisation and causation in regard to very large sections of the continents must necessarily rest on a rather insecure foundation. The question therefore arises-how can this be remedied ?

The basis of our knowledge of large parts of the southern continents and of Asia depends largely upon the accounts of primary exploration, some of the best of it contributed by the great pioneers, the naturalist travellers of the nineteenth century. Since their day the mesh of the net has become closer ; but the records of exploration having the character of traverses must nearly always be limited, since observations are usually confined to one season of the year.

The suggestion which I have to offer applies rather to regions where pioneer exploration is regarded as finished, and especially to the colonies and dependencies of the more advanced nations. I submit that these regions offer the most fruitful field for geographical research in the nearer future. As the chief reason for this belief I would mention the justifiable hope of the rapid extension of systematic surveys in such countries; and we are agreed, I think, that the basis of all sound geographical research is a reliable topographic map, supplemented if possible by the results of geological surveys.

Let us consider Africa as an example, with special attention to its inhabitants. Anthropological literature has dealt very fully with the African races and is prepared to answer most of the questions that are usually asked relating to the natives. Nevertheless, the geographical controls or influences affecting the material life of these peoples usually receive far too little attention. Indeed, the physical environment as a rule is quite inadequately treated in the anthropological literature of the continent. A Research Committee of the British Association was therefore appointed

*From the presidential address entitled "Co-operative Research in Geography, with an African Example" to Section $\mathrm{E}$ (Geography) of the British Association, delivered at Aberdeen on September 6 . The full address is being printed in the November issue of the Scottish Geographical Magazine. after the Oxford meeting in 1926 to investigate the state of knowledge of the human geography of inter-tropical Africa; and this Committee has been increasing its activities ever since. It set itself to state clearly the points upon which information was badly needed, and then proceeded to lay plans for tapping a body of knowledge which it believed to exist in Africa, but which hitherto had scarcely been tapped in the interests of geography. Scattered throughout this continent are many men and women, chiefly the district officers of Colonial Governments and missionaries, who, with long residence in close contact with the Africans and personal experience of the environmental conditions year in year out, should be able, by answering specific questions, to provide the essential link between the land and the mode of life of the natives. To them the Committee sent nineteen questions, most of which might be considered to apply to any of the regions envisaged.

\section{Human Geography of Northern Rhodesta}

The most comprehensive response received so far has come from Northern Rhodesia, with the result that the Committee has at its disposal a series of thirty reports by the District Officers of the Protectorate covering nearly the whole territory.

The inquiry has elicited certain facts about the modification of the natural vegetation by the natives. The great majority of the people live upon their crops, and most of these are raised in partial clearings of the savanna. The natives are truly men of the trees, apart from which they cannot live. The essential feature of their system of shifting agriculture is the annual felling or pollarding of trees, and the application to the soil of the ash derived from burning the wood on the site of their gardens. The area of woodland cut for a garden of given size of course depends first upon the luxuriance of the trees, and secondly upon the nature of the practice-whether pollarding or felling. The estimates of the ratio of timber area cut to area of garden vary between $4: I$ and $10: 1$. The estimates of the period required for recovery of the woods are more numerous, but they are difficult to interpret in view of the inadequate accounts of the vegetation. Several District reports mention rest periods as short as four or five years; in others these are between ten and twenty, and in Barotse thirty to thirty-five years.

The degree in which the savanna has degenerated under this system of agriculture depends largely 
upon the density of the population. Many writers point out that tracts of the natural vegetation still exist simply because the population is small-as, for example, in Chinsali with three per square mile. But such figures are misleading, for the actual densities on land desirable from soil and water qualities are very much greater. Moreover, the native cuts wood for many purposes besides that of manuring his garden. Finally, there is the damage to seedlings and young trees caused by the annual grass fires which sweep the territory, started for various reasons.

\section{Externat INFLUENCES}

village of large size by smaller groups varying according to local geographical conditions.

\section{Population Density}

The average density of population for the whole Protectorate is a little more than four per square mile; but it is unevenly distributed. Thus, two Districts in Barotse Province, Kalabo and Mongu, have densities of $11 \cdot 6$ and $16 \cdot 3$ respectively; Chienji on Lake Mweru has 13, while Fort Jameson has $20 \cdot 8$. On the other hand, in a belt from the Katanga border southward to Sesheke the District densities vary from $1 \cdot 3$ to $2 \cdot 5$, while in the railway belt to the east of this, figures are between 3 and 4 .

The effect of European influence upon the economic and social structure of native society in Northern Rhodesia has recently been very thoroughly dealt with by Mr. Merle Davis. Yet it is interesting to attempt an estimate, based upon our District reports, of the nature and degree of external influence upon the material life of the natives. The use of manioc $(C f$. Fig. 3), and the square or oblong type of house which to-day prevails in the north-west, seems to result from indirect contacts with the Portuguese on the Atlantic seaboard. Since 1917, the new wave of immigrants from Angola has led to the spread of this house type throughout the upper Zambezi basin.

Much more important are the influences due to British rule and partial settlement by European farmers, the rapid exploitation of minerals in the Belgian Katanga and the Ndola and Broken Hill Districts of the Protector-

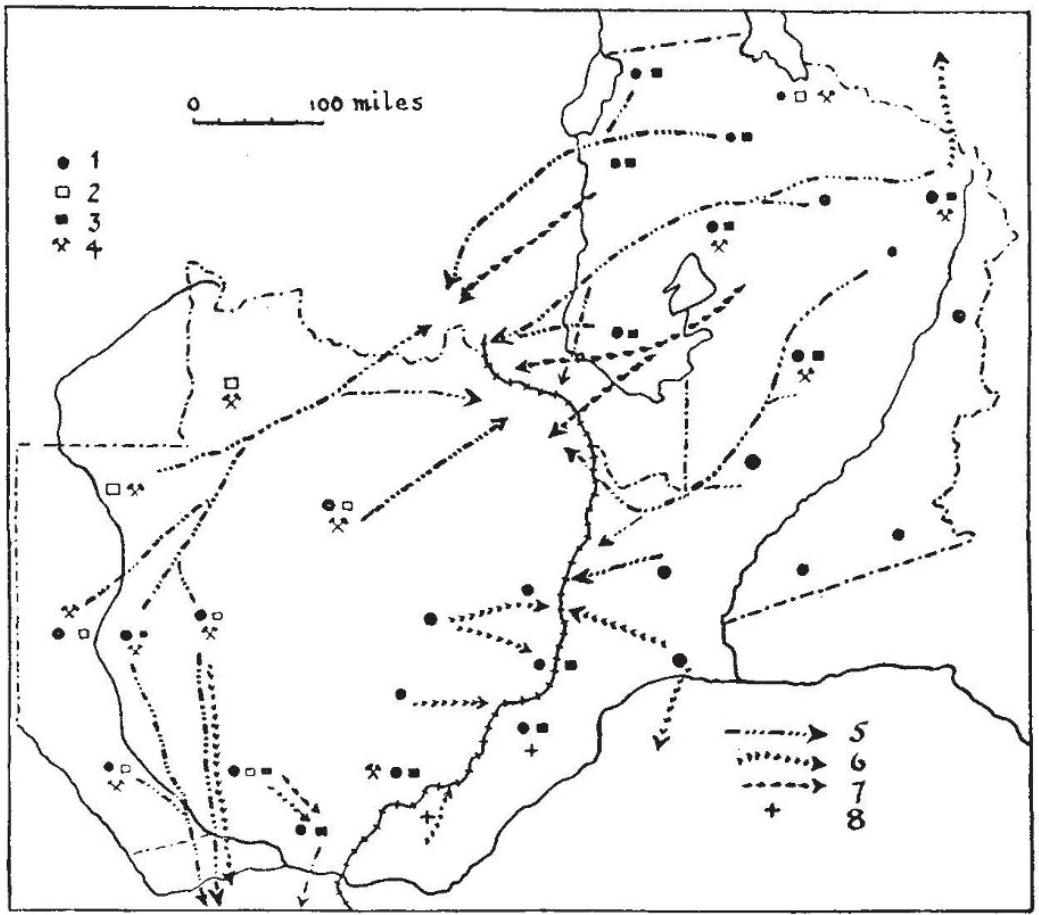

FIG. 1. Cartogram of Northern Rhodesia to illustrate effects of external influences. (1) Rhodesian circular house ; (2) rectangular house of Bantu or Swahili origin ; (3) rectangular house on European model ; (4) native iron industry reported as still in ment and (7) to market produce ; (8) surplus produce sold locally.

ate ; while the establishment of missions throughout Rhodesia has had widespread material as well as moral effect. Indexes of the outward evidence of this permeation are: the distribution of houses built on the European pattern ; the continuance or otherwise of the old-established native iron industry ; and the direction and volume of movement of native labour to work for Europeans (Fig. 1).

It is evident from the reports that while European influence is greatest along the central railway belt, yet the attraction of the mines as a source of employment and a market for surplus food is widespread, though variable, throughout the Protectorate. A universal effect of the new security is the replacement of the old stockaded
But it is the examination of life conditions which brings realisation of the real arrangement of the natives. For example, in Mkushi they live along the river valleys with a probable density of 50-60 per square mile instead of $2 \cdot 77$ for the District.

The type of locality which carries the greatest population is that which provides a means of livelihood apart from agriculture; and fishing is by far the most usual supplement of this kind. Indeed, it becomes the dominant occupation around Lakes Bangweolo and Mweru, where the islands and shores have about 80 persons per square mile. Such areas of good fishing which are also excellent land for producing manioc have received access of population in recent years on account of the 
encouragement to market fish and meal in the mining areas to the west. The great alluvial plains of the Barotse, the Kafue Flats, and the reserves east of the Luangwa are all relatively populous districts in which cattle are held by cultivators. Apart from the areas mentioned and a few others less notable, the population densities, calculated on the assumption of stream-bank arrangement, would seem to vary from, say, 5-10 per square mile in Districts of small population to $40-50$ in the more populous.

\section{Tsetse Fly}

No element of the human environment is more important than the distribution of the tsetse flies

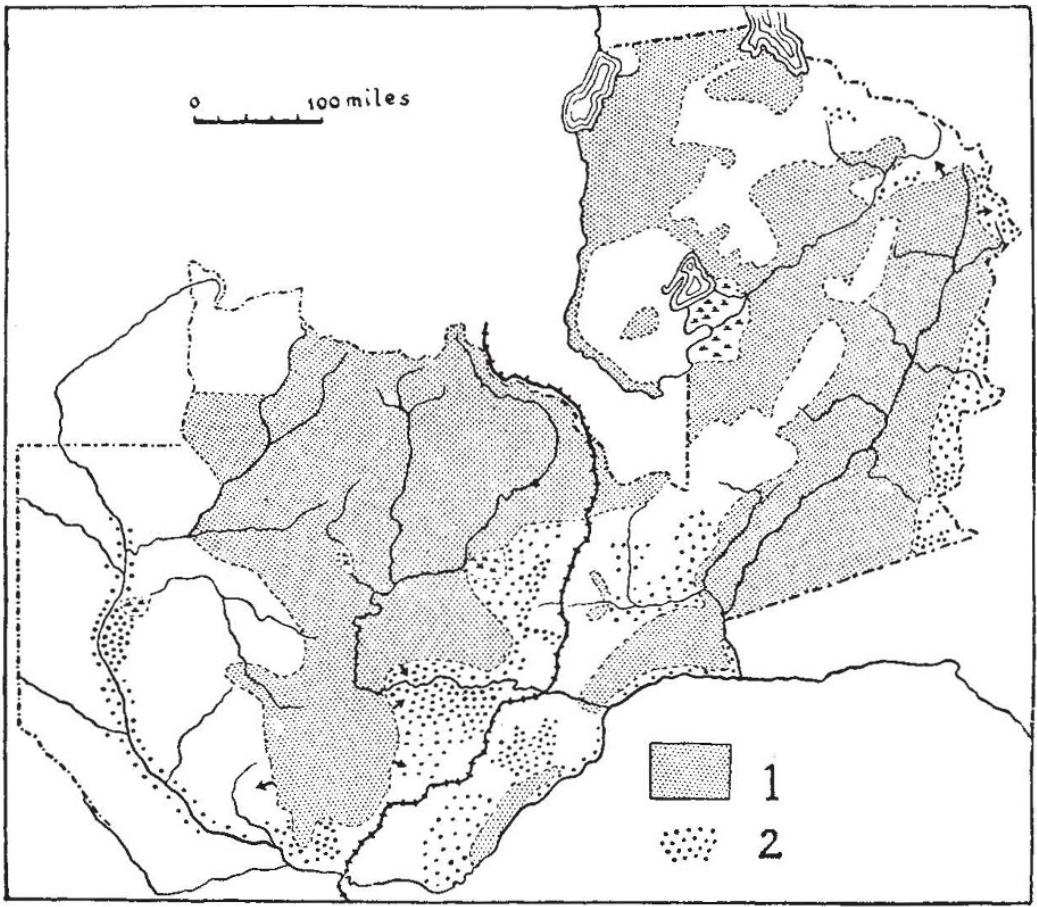

FIG. 2. Sketch-map of Northern Rhodesia, showing distribution of (1) tsetse fly and (2) native-owned cattle.

(Glossina). G. palpalis, the carrier of sleeping sickness, appears happily to be either absent or innocuous over nearly all the country. But with the bearers of Nagana it is quite otherwise. Their distribution, as plotted from the reports and certain local maps, reveals three large tracts that are free of fly. The first includes the greater part of Barotseland. East of this lies a broad fly belt; within this the flies seem to be spreading, and at the southern end the belt is extending both eastward and westward toward the native and European cattle land of the lower Kafue and the railway zone. This latter, with its greater amount of cultivated land, is still free of fly to the edge of the great escarpment, and the same is generally true of its continuation north-eastward along the divide between the Chambezi and Luangwa; Broken Hill and Mkushi even report a reduction in fly. The Luangwa fly belt shuts off the clear area of the Nyasaland border, and at the head of the valley the pest is encroaching on the plateau land. The tsetse distribution is more patchy in the northern areas. Generally speaking, the higher lands are the freer. In Fort Rosebery the fly is local, and Kasama records a reduction; but evidently there are few areas which can safely be reached by cattle.

Fig. 2 indicates clearly the prevalence of tsetse in the hot lowlands, but the controlling factor on the plateaux, which is doubtless the character of the vegetation, cannot be examined until a survey of that element has been made. The nature of the wild fauna is a contributory factor; and while the reports contain useful information regarding the wild animals which are hunted or cause depredations to crops, it is insufficient to allow of any important deduction.

\section{Cattree}

While cattle are restricted to the areas free of fly, they are by no means evenly distributed throughout these parts. Nor are they of equal significance in the life of their owners, chiefly on account of varying tribal tradition in regard to cattle, but also from the incidence of European influence. In Barotse the herds vary according to the available pasture, being greatest on the Zambezi plain (in Mongu circa 50,000 head) and decreasing north and south. Cattle in general are regarded merely as wealth, chiefly in relation to the marriage security, sometimes as a source of meat and of hides, more rarely of milk. But in contact with Europeans and a market, the tribesman tends to devote his animals to work, notably with the acquisition of the plough in the alluvial plains, of two-wheeled carts on suitable ground and of sledges elsewhere. It is chiefly in the vicinity of the railway that the natives are following European guidance in the matter of breeding and of dipping. Elsewhere the herds receive little attention, and consequently the stock is poor. Furthermore, the Barotse cattle were stricken with pleuro-pneumonia in 1915 and their numbers reduced by perhaps 50 per cent. In the central 
Districts, on the other hand, stock is increasing, owing to the natives' contact with Europeans. Here there is some danger from overstocking, which reacts not merely directly on the animals, but also results in rapid erosion of the soil wherever there are slopes.

Transhumance is practised by the cattle owners of the Barotse Plain and the Kafue Flats, in each case in response to the flooding of the alluvial belt ; and in each case this has great effect upon the social and economic life of the tribes concerned.

\section{Food Staples}

The distributions of four of the leading food crops of Africa meet and overlap in Northern Rhodesia; the three cereals, comprising the great millet (sorghum), the lesser millets, of which eleusine is the most important, and maize. These, with manioc (cassava), form the food staples of the native population. Allowing for some uncertainty as to the identity of the millets mentioned by the authors of reports, it has been possible to plot the crop distribution with general accuracy (Fig. 3). It is thus evident that the small millets, especially eleusine, prevail in the north-eastern plateau, while sorghum is more cultivated in the central Districts. This crop, however, has yielded the first place over most of its area to maize, most probably introduced from the south and certainly increasing where the contact with European farming is close. The most outstanding fact elicited is the penetration of the territory by manioc as a staple crop. The lower Congo region is generally held to have been the centre of dispersion of this American plant, and it will be interesting to learn whether its area is now unbroken to the Rhodesian border. It is clear that manioc is still being carried south-eastward by the Angolan immigrants in Barotse, and, for several reasons, its cultivation is being encouraged elsewhere by the administration. The dependence upon these crops is closely related to the distribution of soil and vegetation types, to the incidence of rainfall and to the annual flooding of the rivers.

In addition to the matters referred to, this piece of co-operative research in human geography has yielded much information upon animal pests and the amount and nature of hunting; upon fishing in relation to the rise and fall of rivers; upon the seasonal migrations in search of fish and various food relishes. Most important of all is the whole subject of seasonal rhythm of occupation and its regional variations, a matter upon which the reports are of great service.

It is much to be hoped that surveys of the other African territories will be undertaken. Moreover, I am looking beyond Africa to countries where many Europeans reside, people who may never have thought of geography as we regard it, but who might well be sufficiently interested in the land of their choice to be willing to take part in the kind of team work which I have outlined. Take India as an example. In spite of voluminous official and other

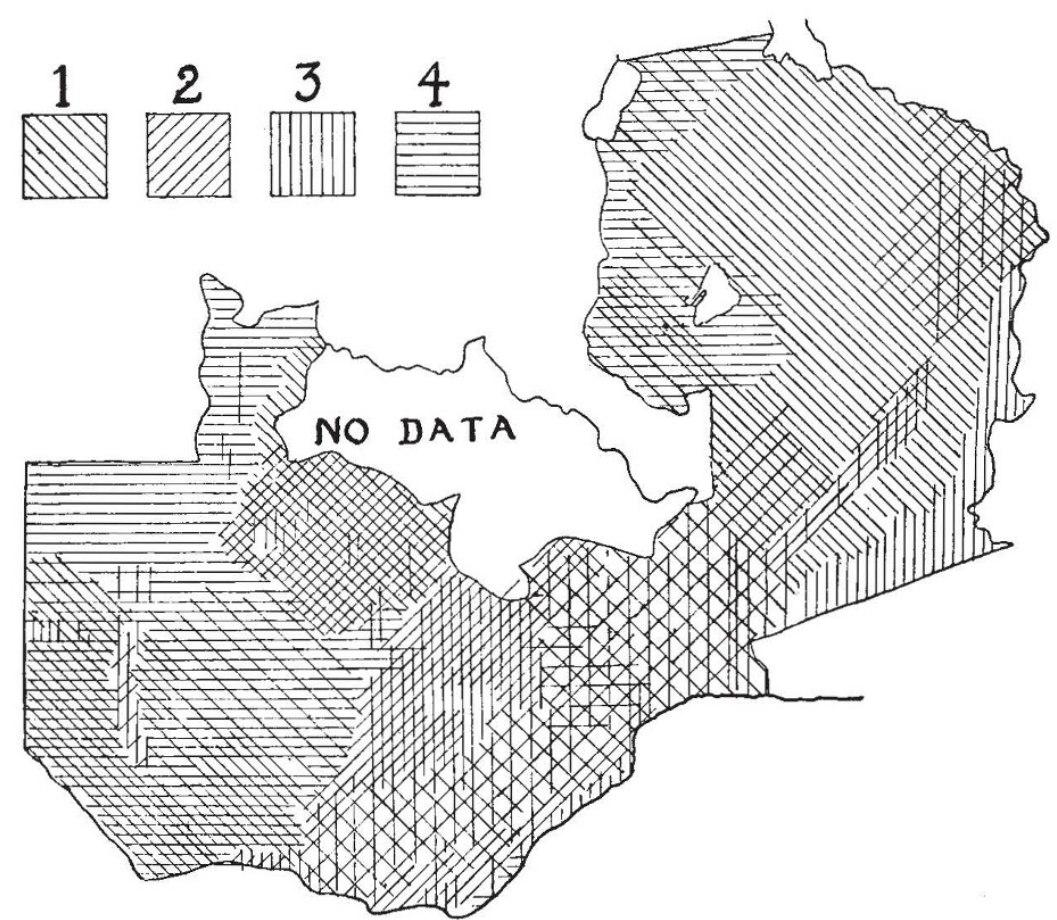

Fig. 3. Cartogram of Northern Rhodesia, showing distribution of leading food staples. (1) Small millet, generally eleusine; (2) sorghum; (3) maize; (4) manioc (cassava).

literature, we have still a great deal to learn of the geography of man in the sub-continent. Although the task of gathering theinformation there would be much more complex than in the case of Africa, there would be certain offsetting advantages. Among these are: the accuracy of the map of India, the existence of agreat body of data created by the various scientific services, and a wonderful census organisation. In addition, there is the likelihood that men of science could be found on the spot who would be able to fill in the gaps in the picture of the physical environment. These might be asked to deal with the numerous connecting links which are not usually required for official departmental reports, but are, nevertheless, essential to the geographer. 